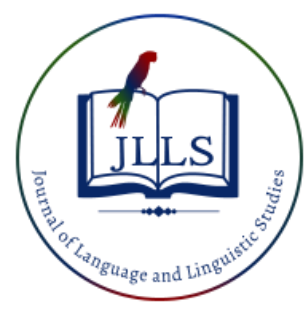

Available online at www.jlls.org

JOURNAL OF LANGUAGE AND LINGUISTIC STUDIES

ISSN: 1305-578X

Journal of Language and Linguistic Studies, 16(4), 1885-1898; 2020

\title{
The analysis of illocutionary acts of judges' comments in America's next top model and Asia's next top model competitions: A cross-cultural pragmatic study
}

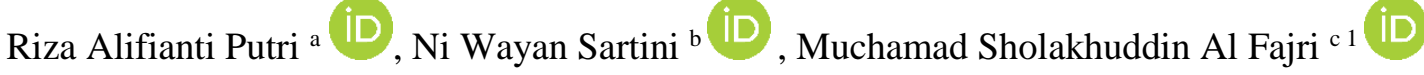 \\ ${ }^{a}$ Universitas Airlangga, Surabaya, Indonesia \\ ${ }^{b}$ Universitas Airlangga, Surabaya, Indonesia \\ ${ }^{c}$ Universitas Airlangga, Surabaya, Indonesia
}

APA Citation:

Putri, R. A., Sartini, N. W., \& Fajri, M. S. A. (2020). The analysis of illocutionary acts of judges' comments in America's next top model and Asia's next top model competitions: A cross-cultural pragmatic study. Journal of Language and Linguistic Studies, 16(4), $1885-1898$.

Submission Date: 20/07/2020

Acceptance Date:31/08/2020

\begin{abstract}
This study discusses speech acts performed by judges of model competitions in America and Asia TV series America's Next Top Model and Asia's Next Top Model. The aim of this study is to find out the illocutionary acts of the judges since they are considered as the decision makers in a competition. The detailed analysis between American and Asian cultures is presented to support the findings of the study. For the data of the study, we collected utterances in the America's Next Top Model Session 21 Episode 5 and Asia's Next Top Model Session 6 Episode 1 from YouTube. In analysing the data, we transcribed all utterances using orthographical transcription method. The data were then analysed and categorized in terms of the theory of illocutionary speech acts from Searle (1979) using qualitative description method. After that, we made an interpretation based on the collected data and generated conclusions as well as suggestions for further research. From the analysis, it could be concluded that the total illocutionary speech acts were 146 utterances ( 72 from America \& 74 from Asia). The major types in America's Next Top Model were assertive and declarative (33.33\%), while expressive function turned out to be the most dominant one in Asia's Next Top Model. In cross-cultural pragmatics point of view, the results of this study conclude that Asians were more expressive than Americans. In addition, there was an apology statement in the American context whereas there was no expression of apology in the Asian context. In this study, it could also be seen that Americans were more to the point or overt than Asians whereas Asians were categorized to be more "careful" than Americans.
\end{abstract}

(C) 2020 JLLS and the Authors - Published by JLLS.

Keywords: speech act; illocutionary act; cross-cultural pragmatics; America's Next Top Model; Asia's Next Top Model

\section{Introduction}

In daily life, people utilize language to communicate and produce a code. According to Utaker (1992), code or system is defined as the spoken words produced by people during conversation. This code is a human intermediary in order to create a good communication system between speakers and listeners. To be able to communicate, both need to have a common understanding of certain languages.

\footnotetext{
${ }^{1}$ Corresponding author.

E-mail address: m-sholakhuddin-al-fajri@ vokasi.unair.ac.id
} 
For example, the English people will not understand the Indonesian language if they do not have knowledge about Indonesian and vice versa. Therefore, both speakers and listeners require to possess the same knowledge of a particular language in the same subject matter in a certain time, place, and situation.

In the communication process, there is a term called "Speech Act" which is not only limited to the communication dimension itself. As mentioned before, both speaker and listener are required to speak the same language and have insight into the use of that language for the communication process. Speech act theory is considered under the study of pragmatics. Pragmatics is the study of the meaning of utterances which are different from the literal meaning of words or sentences depending on the context (Cumming, 2005; Thomas, 1995; Yule, 1996). In other words, pragmatics is the study of words and utterances conveyed by the speaker in a certain context. As stated by Leech (1983), pragmatics is a study which deals with the situation of speaking.

Austin (1962) defines speech act as the reaction or action when people say something. In other words, someone is doing something by saying something. Speech act is not only related to the language itself, but also connected to something beyond language, such as context (Birner, 2013; Cutting, 2008). Speech act in case of communication is associated with the functional dimension of language (Bayat, 2012). In contrast to the morphological, syntactic, and rhetorical dimensions which are more concerned with the structure of language, the pragmatic dimension is associated with producing and understanding the speech itself. These two dimensions function reciprocally in communication. According to Bayat (2012), the use of appropriate speech acts is gained through cultural experience to realize social relations. Searle (1979) also highlights that speech acts are conveyed in real language use situations. Therefore, it is stated that the basic assumption in speech act theory or the smallest unit in human communication is the implementation of certain types of actions.

Speech act theory was introduced by Austin (1962) and then divided into three categories, namely locutionary act, illocutionary act, and perlocutionary act. However, this study only focuses on the illocutionary act which is defined as an utterance containing certain (conventional) power to do several actions (Austin, 1962; Grice, 2011). The speaker could perform a certain action through speaking with the function as informing, claiming, guessing, warning, threatening, or asking. In other words, illocutionary act (The Act of Doing Something) is an utterance which is not only used to say or inform something, but also to do something as long as the speech situation is carefully considered (Levinson, 2001; Wijana, 1996). In this case, John R. Searle (1979) classifies illocutionary acts into five different functions namely, assertive, directive, commissive, expressive, and declarative.

Representative or assertive type is a statement that reports a fact statement that can be verified as true or false (Mayer, 2009). The examples are statement of stating, telling, demanding, boasting, reporting, complaining, proposing, and claiming. The second type is directive; speech acts or utterances that are intended to make someone do something, such as asking, ordering, pleading, suggesting, advising (Grundy, 2000; Huang, 2007). Thus, the commissive type is intended to the speaker to take some actions in the future such as promising, swearing, offering, and saying (praying). In addition, expressive speech act has a function to express the speaker's attitude. This type of speech act thus shows the psychological attitude of the speaker in a specific situation, such as thanking, apologizing, praising, blaming, congratulating, forgiving and condolences. Lastly, the declarative speech act is intended by the speaker to create a new thing or change a condition or status. The successful implementation of this illocution will lead to conformity between the contents of proportion and reality, such as surrender, dismiss, release, baptize, exclude, appoint, and determine. Table 1 shows types of illocutionary act with examples. 
Table 1. Types of illocutionary acts with examples

\begin{tabular}{lll}
\hline No & Types of illocutionary act & Examples \\
\hline 1 & Assertive & The pen is on the table \\
2 & Directive & I want you to read the book \\
3 & Commissive & I promise to visit my parent tomorrow \\
4 & Expressive & I apologize for my mistakes \\
5 & Declarative & The judge sentences him to four months in \\
& & prison \\
\hline
\end{tabular}

The way people produce speech act depends on the context. There are many influencing factors including gender (Tuncer \& Turhan, 2019) and culture. Basically, someone's illocutionary words or actions will affect one's understanding of doing an action. In this case, pragmatics also intersects with other cultures, commonly called as cross-cultural pragmatics (Wierzbicka, 2003). One of the examples can be observed in international models competition entitled America and Asia Next Top model. The reason for choosing these competitions is the similarity of the two programs, in that both TV series provide similar natural conversation but occurred in different contexts or cultures. Thus, we conducted a study of speech acts performed by the judges in well-known models competition taken from the TV series America's Next Top Model and Asia's next Top Model. This article focuses on illocutionary speech acts of comments produced by the judges. We also made detailed observations about cultural differences between America and Asia in commenting the contestants.

America's Next Top Model and Asia's next Top Model are one of the interesting TV series to observe because they are recognized as international events and considered as the first gate to be a famous worldwide model. There have been several top models born from this competition. In addition, America's Next Top Model has 24 series until 2018 and was nominated at the GLAAD Media Awards in 2004, 2006, 2009 as the Outstanding Reality Program, and also won the Directors Guild of America and Ten Choice Award 2009. By the time, the management intended to extend this competition to different areas including Asia in 2012.

As stated above, the researcher focused on the judges' comments in the America's Next Top Model and Asia's Next Top Model. It is interesting to analyse since a judge is defined as someone who decides contestant career to the next stage. Besides, a judge is a decision maker in a competition. Therefore, the judges' comments are considered crucial in the development of participants by giving suggestions or advice for the success of the contestants in each performance. Therefore, we are interested in examining the illocutionary actions uttered by the judges in giving comments which sometimes imply something more than what they say. Due to a large number of sessions that have been broadcast by these TV programmes, we limit this study to only one episode, namely America's Next Top Model session 21 episode 5 and Asia's Next Top Model session 6 episode 1.

There are several studies related to the use of illocutionary speech acts in several different contexts. In the classroom setting, Budiasih et al. (2016) conducted a study on illocutionary acts of foreign students in Indonesian learning setting by concerning the learning process. Malenab-Temporal (2018) investigated ESL learners' speech acts in classroom discourse. These studies showed that in the classroom, most illocutionary acts are used for asking questions, giving opinions and confirming. Illocutionary act analyses have also been conducted on speeches. Rosyidi et al. (2019), for example, examined illocutionary speech act use by Jokowi in first Indonesia presidential election debate in 2019. Putri (2018) investigated Illocutionary Acts in Donald Trump's Inauguration Speech. Both studies demonstrated that illocutionary acts in political speeches are frequently employed for giving 
opinion, promising and convincing. As another text type, Sholihatin (2020) analysed illocutionary and perlocutionary speech acts in defamation texts. She found that illocutionary acts used include representative, declarative, and directive. The review of these previous studies serves to show that each genre of texts employs different functions of illocutionary acts.

However, the previous studies only discussed different aspects of speech acts in one subject only, such as in the context of classroom and political speeches. We found limited research on illocutionary acts linked to cultural aspects, particularly Indonesian cultures. Cross-cultural pragmatic studies focus more on politeness (e.g. Nureddeen, 2008; Spencer-Oatey \& Jiang, 2003). Therefore, it is important to figure out how speech acts especially illocutionary acts are applied in different contexts by identifying the relationship of speech acts with other cultural aspects, particularly American and Asian cultures. Furthermore, this paper aims to find out the types and functions of illocutionary speech acts performed by judges' comments of America's Next Top Model and Asia's Next Top Model. The significance of this research is to provide and enrich better insight into cross-cultural pragmatic research, especially illocutionary acts that also consider cultural aspects.

\section{Method}

This study used qualitative descriptive method. As stated by Dörnyei (2007), the qualitative approach takes more attention to the idiosyncratic aspects of human experience. Besides, a qualitative approach also refers to data description of situations or phenomena in natural context. The main point is to illustrate the reality based on subjective and personal interpretations. Thus, the purpose of qualitative research is to obtain a complete description and in-depth understanding of social phenomena, rather than numerical analysis of data. This is in accordance with the main point of this study which discusses the judges' personal comments and perspective.

It is known that America's Next Top Model and Asia's Next Top Model are the world's leading model competition which consists of several sessions and episodes. In this study, we only investigated one episode in a session, namely America's Next Top Model Session 21 Episode 5 and Asia's Next Top Model Session 6 Episode 1. The data were taken from YouTube and then transcribed by using an orthographic method. The data comprised 126 utterances for American episode and 115 utterances for Asian's which focus on three judges on each episode. The data were then categorized into types of illocutionary acts by Searle (1979). After that, we made an interpretation, followed by conclusions and suggestions for further research.

\section{Results and Discussion}

\subsection{Types and Functions of Illocutionary Acts in Judges' Comments of America's Next Top Model}

Based on the analysis, we found four types of illocutionary act, namely assertive, directive, expressive, and declarative. However, the commissive type was not found in the data. The data findings are presented in Table 2. 
Table 2. Types of illocutionary acts in the judges' comments of America's Next Top Model

\begin{tabular}{cccc}
\hline No & $\begin{array}{c}\text { Types of } \\
\text { Illocutionary } \\
\text { Acts }\end{array}$ & Frequency & Percentage (\%) \\
\hline 1 & Assertive & 24 & 33.33 \\
2 & Directive & 3 & 4.17 \\
3 & Eexpressive & 21 & 29.17 \\
4 & Declarative & 24 & 33.33 \\
\hline & Total & 72 & $100 \%$ \\
\hline
\end{tabular}

Table 1 presents 72 illocutionary acts found in the judges' comments of America's Next Top Model out of 126 utterances. It could be seen that assertive and declarative types are the most dominant type and both have the same number of 24 occurrences or $33.33 \%$ respectively. In addition, the expressive type also has a high number of utterances, with 21 utterances or $29.17 \%$. The lowest frequency of illocutionary acts is directive with only 3 utterances (4.17\%). Meanwhile, commissive type was not found in this data.

In the judges' comments of America's Next Top Model, there are several functions contained in a speech. We discovered several speech act functions performed by the judges of America's Next Top which are presented in Table 3.

Table 3. Types and functions of illocutionary act in judges' comments of America's Next Top Model

\begin{tabular}{|c|c|c|c|c|c|}
\hline No & $\begin{array}{c}\text { Types of } \\
\text { Illocutionary Acts }\end{array}$ & Function of Speech Act & Frequency & $\begin{array}{c}\text { Percentage } \\
(\%)\end{array}$ & $\begin{array}{c}\text { Total } \\
\text { Frequency }\end{array}$ \\
\hline \multirow{4}{*}{1} & \multirow{4}{*}{ Assertive } & Informing & 3 & 4.17 & \multirow{4}{*}{24} \\
\hline & & Suggesting & 3 & 4.17 & \\
\hline & & Complaining & 14 & 19.44 & \\
\hline & & Boasting & 4 & 5.56 & \\
\hline \multirow{2}{*}{2} & \multirow{2}{*}{ Directive } & Advising & 2 & 2.78 & \multirow{2}{*}{3} \\
\hline & & Recommending & 1 & 1.39 & \\
\hline \multirow{4}{*}{3} & \multirow{4}{*}{ Expressive } & Congratulating & 1 & 1.39 & \multirow{4}{*}{21} \\
\hline & & Apologizing & 2 & 2.78 & \\
\hline & & Thanking & 2 & 2.78 & \\
\hline & & Praising & 16 & 22.22 & \\
\hline 4 & Declarative & Determining & 24 & 33.33 & 24 \\
\hline \multicolumn{3}{|c|}{ Total } & 72 & $100 \%$ & 72 \\
\hline
\end{tabular}

Table 2 indicates that the most frequent illocutionary act used by the judges is determining, with 24 utterances or $33.33 \%$. This kind of function belongs to declarative type. In addition, the second highest frequency is the function of praising with 16 utterances or $22.22 \%$ followed by complaining by 14 utterances or $19.44 \%$. In this data, there are two functions with the lowest number of occurrences, namely recommending and congratulating with 1 utterance or $1.39 \%$.

As stated earlier, there are 4 types of illocutionary acts produced by judges in America's Next Top Model. Each type contains certain functions which will be discussed in the following sections. 


\subsubsection{Assertive}

a. Informing

(1) You know our judges, the stars is Kelly Cutrone, fashion Maven PR and Miss J Alexander

The example above belongs to the informing function of assertive type. In this case, the main judge introduces the names of all judges who will be the decision makers of the model's performance. This context takes place in the first part of the session informing the judges' name and background. All the explanation denotes that all judges are the professionals who have a good influence in modeling industry. The example above mentions that one of the judges is Kelly Cultrone, a Maven's Public Relation. Public Relations positions are considered to have a broad network to get jobs for catching better career paths. It requires to be highlighted to all contestants that if they give their best performance, the participants could find work easily with the help of the judges.

\section{b. Suggesting}

\section{(2) ... he has a fantasy head role could have been a little more than a serious fantasy}

In data above, the judge gave the direction and suggestion regarding their performance, in that he considered the performance of one of the contestants as not satisfying. The judges considered that the performance would be better if the contestant gave more serious fantasy sensation than before.

(3) You get an eight for me and it would be higher if you didn't do this weird thing with your flick

The example above shows the judge's suggestion to one of the contestants as not to act badly because it could influence the score of competition. It is clear that the participant could get a better score if he avoided that action.

\section{c. Complaining}

(4) I just want more from you.

The utterance above represents a complaint reaction of judges because of disappointment with one of the contestant's performance. The short sentence above signals that the contestant could be better with his abilities.

(5) So Linux I am super-duper disappointed with this commercial.

This sentence also expresses that the judge felt disappointed with Linux's performance at that time. They suggested that she had not presented an optimal show in competition. It could be seen from the word " super-duper" which emphasizes the disappointment of the judge.

\section{d. Boasting}

(6) I feel like we really worked the hair you know is one of my favourite makeovers in Top Model history. 
In this case, Tyra Bank, one of the judges, as the producer and founder of the Asia's Next Top Model expressed her pride with the makeover or new appearance of one of the models. The word "really" here emphasizes that the contestant has the best performance in the history of America's Next Top Model.

(7) And I feel it and I feel so proud that I gave it to you because I thought you were serving it.

The sentence above also implies that the jury boasted one of the contestants, indicated by the word "proud". The repetition of "I feel" also emphasizes that the judges greatly boasted about the results. The rest of the words here supports the feeling of satisfying by the participant's good performance.

\subsubsection{Directive}

\section{a. Advising}

(8) When somebody has a goal and they see it and they say they want that but they are not willing to do everything to sacrifice

In the above statement, the judge tries to give advice to the contestants who showed bad performance. He said that if you had the desire to be the winner, participants had to pursue it in a serious way. The words "willing to do everything to sacrifice" imply that struggle is needed to reach a certain target. This statement emphasizes that the contestants have to work hard in the competition.

\section{b. Recommending}

(9) I want you guys to watch it denzel's face; it is sexy, it is modely, he's doing these tiny little, he's almost like inhaling and exhaling and doing this really cool thing

In this case, the judge gave a comment to a performance of one of the contestants which was considered to be an appropriate performance. The invitation sentence "I want you guys to watch it denzel's face" emphasizes the recommendation for other models to have that expression in the session which are categorized as a good way of expressing feeling.

\subsubsection{Expressive}

\section{a. Congratulating}

(10) So Ben congratulations on that challenge

The data above is a congratulatory expression because one of the contestants named Ben has successfully passed his challenge. The word "congratulations" is the point of expressive speech act of congratulating.

\section{b. Apologizing}

(11) Sorry, I give you a seven. 
In this case, one of the judges apologized before giving a score to contestant. The word "sorry" in giving this score signals that the contestant could get a better score if he gives his best in performance.

\section{c. Praising}

(12) I really love the way that you made eye contact with the camera and the way that you interacted with Keith for me was sexual but without being too sexy.

Data 12 shows praising statement to the contestants due to great expressions in the camera. This is shown from the expression "really love", emphasizing that the performance of the model has been considered satisfactory.

\subsubsection{Declarative}

\section{a. Determining}

(13) This is the first time I've given a 10 this season.

The sentence above has determining function in that the contestant is assessed and given a perfect point. Point 10 is an affirmation in a declarative which functions as determination. The sentence above also gives the information that this is the first time in the history the judge gives 10 .

\subsection{Types and Functions of Illocutionary Acts in Judges' Comments of Asia's Next Top Model}

This study found four types of illocutionary acts occurred in the judges' comments of Asia's Next Top Model, namely assertive, directive, expressive, and commissive speech acts. In Asia's session, we discovered that declarative speech act was not found in the data. The data are illustrated in Table 4 below.

Table 4. Types of Illocutionary Acts in the Judges' Comments of Asia's Next Top Model

\begin{tabular}{cccc}
\hline No & $\begin{array}{c}\text { Types of } \\
\text { Illocutionary } \\
\text { Acts }\end{array}$ & Frequency & Percentage (\%) \\
\hline 1 & Asertive & 27 & 36.48 \\
2 & Directive & 13 & 17.57 \\
3 & Expressive & 29 & 39.19 \\
4 & Commisive & 5 & 6.76 \\
\hline & Total & 74 & $100 \%$ \\
\hline
\end{tabular}

From the total of 115 utterances, there are 74 utterances containing illocutionary acts with expressive type, turning to be the highest frequency (29 times or 39.19\%) followed by assertive type (27 times or $36.48 \%$ ). In addition, the directive is accounted for 13 utterances or $17.57 \%$. Commissive speech acts have the lowest frequency with only 5 utterances $(6.76 \%)$. However, we did not find declarative type in Asia's data.

In producing utterances, there are several functions performed by Asian's judges. We discovered several speech act functions presented in Table 5 . 
Table 5. Types and Functions of Illocutionary Acts in Judges' Comments of Asia's Next Top Model

\begin{tabular}{|c|c|c|c|c|c|}
\hline No & $\begin{array}{c}\text { Types of } \\
\text { Illocutionary Acts }\end{array}$ & Function of Speech Act & Frequency & $\begin{array}{c}\text { Percentage } \\
(\%)\end{array}$ & $\begin{array}{c}\text { Total } \\
\text { Frequency }\end{array}$ \\
\hline \multirow{5}{*}{1} & \multirow{5}{*}{ Assertive } & Informing & 6 & 8.11 & \multirow{5}{*}{27} \\
\hline & & Boasting & 1 & 1.35 & \\
\hline & & Complaining & 14 & 18.92 & \\
\hline & & Affirming & 5 & 6.76 & \\
\hline & & Claiming & 1 & 1.35 & \\
\hline \multirow{2}{*}{2} & \multirow{2}{*}{ Directive } & Advising & 9 & 12.16 & \multirow{2}{*}{13} \\
\hline & & Asking & 4 & 5.41 & \\
\hline \multirow{3}{*}{3} & \multirow{3}{*}{ Expressive } & Encouraging & 1 & 1.35 & \multirow{3}{*}{29} \\
\hline & & Thanking & 6 & 8.11 & \\
\hline & & Praising & 22 & 29.73 & \\
\hline 4 & Commisive & Promising & 5 & 6.76 & 5 \\
\hline \multicolumn{3}{|c|}{ Total } & 74 & 100 & 74 \\
\hline
\end{tabular}

From the table above, it could be concluded that the function of praising in expressive type dominates the judges' comments of Asia's next Top Model with 22 utterances out of 74 utterances (29.73\%). In addition, the next highest frequency is the function of complaining with 14 utterances or $18.92 \%$. Besides, there are three functions with the lowest number of utterances, namely boasting, claiming, and encouraging with 1 utterance or $1.35 \%$. The detailed explanation of four types is given in the following section.

\subsubsection{Assertive}

a. Informing

\section{(14) To say this week has been an eventful one would be an understatement}

The example above shows the informative sentence to all contestants that this week would be a tough week containing numerous activities. Besides, the judge also gives information that there would be elimination session which implies that the contestants have to be ready. In addition, the sentence also gives information that all participants should prepare themselves by giving their best performance.

\section{b. Boasting}

(15) And the jewellery is very well showcased I feel like if I were a jewellery client I'd be very happy with that.

In the sentence above, the judge gives a signal to the participant that she is very proud of his performance. The session theme is a photo shoot using jewellery. This pride is conveyed with satisfying expression to the contestant using the words "happy". Also, the emphasizing of the words "very well and very happy" supports the expression of boasting conveyed by the judges. 


\section{c. Complaining}

(16) You have such beautiful features, that's what's disappointing to not see that beauty is transcribed on that screen.

In this case, one of the judges feels disappointed with the appearance of a contestant. She mentions that the participant is very beautiful and charming but it could not be transferred in the screen. The word "disappointing" gives a clear description that the judge feels disappointed because her beauty cannot be seen on camera.

\section{d. Affirming}

(17) You froze and you stopped, I mean if you're afraid of looking bad, this is the wrong industry for you.

This is one of the affirmative sentences produced by the judge to appeal that the modelling industry demand good looking without fear of being imperfect. The model has to be ready to get an order from the photographer to create a wonderful picture. The judges did not want to see unconfident contestants anymore and ask them to have a good mentality if they intend to stay in modelling industry.

\section{e. Claiming}

(18) I don't know when a judge is efficient because everything that comes with it, it doesn't tell me that you can book a job right now.

The sentence also shows a disappointment by claiming that the contestant will not be able to get a job if he performs in bad way. This is due to the lack of maximum performance of one of the contestants.

\subsubsection{Directive}

a. Advising

(19) You need to take a step, take a moment, check yourself, you have to have a game plan

In this Asian session, the judge gave advice to the contestants to set the strategy before starting the photo session.

b. Asking

(20) Adela della della, how's your eyes?

The context is when the model has a photo session with animals and the contestant named Adela has some problems with her eyes because of the animal. This sentence refers to asking function to show the sympathy about contestant's condition. 


\subsubsection{Expressive}

a. Encouraging

\section{(21) Good luck girls. It's an honour to be here}

The phrase "Good luck" is a form of encouragement expression produced by the judges to show their support. They also wish to see great and satisfying photoshoot in the competition.

\section{b. Thanking}

\section{(22) Thank you, Roubini.}

The sentence above is a thankful expression given to participants. This is used to give appreciation for giving their best performance.

\section{c. Praising}

(23) We don't know where you end and the Python starts. You're one with the fake.

The data above is praising utterance because the contestant can show her best performance in a photo session with animals. In this case, the participant has a deep fear of animals but she can give her best appearance. The sentence "You're one with the fake" has a positive connotation refers to praise for the contestant.

\subsubsection{Commissive}

(24) And now ladies, to your prizes: The winner of Asia's next top model will drive home with the all new Subaru XP.

In this context, the judge and the management of the model competition gave promises for the winners of this contest. It is also intended to encourage participants to give their best performance to become the winner.

Regarding the cross-cultural study, we infer that the Asians are more expressive in showing their feelings than Americans (see Table 6 for the comparison). This is obtained from the number of expressive functions in the Asian context by 29 utterances while the American context by 21 utterances. In addition, there is an apology utterance in the American context whereas there is no expression of apology in the Asian context. This is in accordance with Wierzbicka's (2003) analysis that "thank you" and "sorry" are concepts used by western custom and this is very incompatible with Japanese culture. In addition, the determining function could not be found in the Asian context. When it is investigated from the advising function, Asians can be stated to have more empathy to encourage others than Americans. 
Table 6. Illocutionary Acts in Judges' Comments of Asia's Next Top Model and America's Next Top Model

\begin{tabular}{llllll}
\hline \multirow{2}{*}{ No } & Types of Illocutionary & \multicolumn{2}{c}{ Total Frequency } & \multicolumn{2}{c}{ Percentage (\%) } \\
\cline { 3 - 6 } & Acts & $\begin{array}{l}\text { Asia's Next Top } \\
\text { Model }\end{array}$ & $\begin{array}{l}\text { America's } \\
\text { Next Top } \\
\text { Model }\end{array}$ & $\begin{array}{l}\text { Asia's Next } \\
\text { Top Model }\end{array}$ & $\begin{array}{l}\text { America's } \\
\text { Next Top } \\
\text { Model }\end{array}$ \\
\hline 1 & Assertive & 27 & 24 & 36.49 & 33.34 \\
2 & Directive & 13 & 3 & 17.57 & 4.17 \\
3 & Expressive & 29 & 21 & 39.19 & 29.17 \\
4 & Commisive & 5 & 0 & 6.76 & 0 \\
5 & Declarative & 0 & 24 & 0 & 33.33 \\
\hline \multicolumn{2}{r}{ Total } & 74 & 72 & $100 \%$ & $100 \%$ \\
\hline
\end{tabular}

In this study, it can also be seen that Americans are more to the point or overt than Asians. The evidence is shown from the type of declaration with the determining function that is found only in the American context. These results are in accordance with Wierzbicka's (2003) study that Japanese often performs 'indirect' utterances contrasted with the American custom. Western culture tends to be more 'direct'. In other words, people in English speaking countries have more spontaneous attitudes than Japanese people who prioritize politeness.

\section{Conclusions}

In this study we found 4 types of illocutionary acts performed by the judges of America's Next top Model, namely: Assertive, Directive, Expressive, Declarative with a total of 72 utterances. However, in the Asia's Next Top Model episode, we found 4 speech acts namely Assertive, Directive, Expressive, and Commissive, with 74 utterances. In addition, the most dominant types of speech act in America's Next Top Model are assertive and declarative, accounted for 33.33\% while in Asia's Next Top Model there are 29 expressions. In addition, the declarative function is not found in the Asian context while the commissive function does not exist in the American context.

In cross-cultural pragmatics point of view, the results of this study conclude that Asians are more expressive than Americans. In addition, there is an apology statement in the American context whereas there is no expression of apology in the Asian context. In this study, it can also be seen that Americans are more to the point or overt than Asians. Asians seem to have more empathy to encourage contestants by identifying the number of advice functions.

In this article, however, we do not involve elements outside the language itself, such as intonation and facial expression. This needs to be added in further research to enrich the results of the study.

\section{Ethics Committee Approval}

The author(s) confirm(s) that the study does not need ethics committee approval according to the research integrity rules in their country (Date of Confirmation: December 11, 2020). 


\section{References}

Austin, J. L. (1962). How to do things with words. Oxford: Clanrendon Press.

Bayat, N. (2012). A study on the use of speech acts. Procedia - Social and Behavioral Sciences, 70, $213-221$.

Birner, B. J. (2013). Introduction to pragmatics. West Sussex, UK: Wiley- Blackwell.

Budiasih, L. T., Andayani, A. \& Rohmadi, M. (2016). Illocution on speech acts of foreign students in Indonesian learning. Parole: Journal of Linguistics and Education, 6(2), 41-48.

Chaer, Abdul. (2015). FIlsafat Bahasa. Jakarta: Rineka Cipta.

Cummings, L. (2005). Pragmatics: multidisciplinary perspective. Edinburgh: Edinburgh University Press.

Cutting, J. (2008). Pragmatics and discourse: a resource book for students (2nd ed.). Abingdon: Routledge.

Dorney, Z. (2007). Research method in applied linguistic: Quantitative, qualititative, and mixed methodologies. Oxford: Oxford University Press.

Grundy, P. (2000). Doing pragmatics (2nd ed.). London: Hodder Arnold.

Grice, H. P. (2011). Logic and conversation. In D. Archer \& P. Grundy (Eds.), The Pragmatics Reader (pp. 43-54). Abingdon: Routledge.

Huang, Y. (2007). Pragmatics. Oxford: Oxford University Press.

Leech, G. N. (1983). Principles of pragmatics. London: Routledge.

Levinson, S. C. (2001). Pragmatics. Cambridge: Cambridge University Press.

Malenab-Temporal, C. (2018). Conversation analysis of ESL learners' speech acts in classroom discourse. Asia Pacific Journal of Multidisciplinary Research, 6(3), 47-56.

Meyer, Charles F. 2009. Introducing English linguistics. New York: Cambridge University Press

Nureddeen, F. A. (2008). Cross cultural pragmatics: Apology strategies in Sudanese Arabic. Journal of Pragmatics, 40(2), 279-306.

Putri, P. D. S. P. (2018). Representative and commissive illocutionary acts in Donald Trump's inauguration speech. Jurnal Humanis, 22(4), 1057-1062

Rosyidi, A. Z., Mahyuni, M., \& Muhaimi, M. (2019). Illocutionary speech acts use by Jokowidodo in First Indonesia Presidential Election Debate 2019. International Journal of Multicultural and Multireligious Understanding, 6(2), 735-740.

Searle, J.R. (1979). Expression \& meaning: Studies in the theory of speech acts. Cambridge: CUP.

Sholihatin, E. (2020). An analysis of illocutionary and perlocutionary speech act in defamation texts. JOLLT Journal of Languages and Language Teaching, 7(1), 49-56.

Spencer-Oatey, H., \& Jiang, W. (2003). Explaining cross-cultural pragmatic findings: moving from politeness maxims to sociopragmatic interactional principles (SIPs). Journal of Pragmatics, 35(1011), 1633-1650.

Thomas, J. (1995). Meaning in interaction: An introduction to pragmatics. London: Longman. 
Tuncer, H. \& Turhan, B. (2019). Refusal strategies of Turkish pre-service teachers of English: A focus on gender and status of interlocutor. Journal of Language and Linguistic Studies, 15(1), 01-19.

Utaker, Arild. (1992). Form in Language: Wittgenstein and structuralism. Wittgenstein and Contemporary Theories of Language Papers Edited by Paul Henry and Arild Utaker. Wittgenstein Archives: the University of Bergen.

Wijana, I Dewa Putu. (1996). Dasar-dasar Pragmatik. Yogyakarta: Andi Yogyakarta.

Wierzbicka, A. (2003). Cross cultural pragmatic - the semantic of human interaction. New York: Mouton De Gruyter.

Yule, G. (1996). Pragmatics. New York. Oxford University Press.

\section{Amerika'nın yeni en iyi modeli ve Asya'nın sonraki en iyi model yarışmalarında jüri yorumlarına ilişkin edimsel eylemlerin analizi: Kültürler arası pragmatik}

\section{$\ddot{\mathbf{O} z}$}

Bu çalışma, Amerika ve Asya TV dizileri Amerika'nın Yeni En İyi Modeli ve Asya'nın Yeni En Üst Modeli'ndeki model yarışmalarının jüri üyeleri tarafından gerçekleştirilen konuşma eylemlerini tartışmaktadır. $\mathrm{Bu}$ çalışmanın amacı, jürinin bir yarışmada karar vericiler olarak görüldükleri için aldatıcı eylemlerini ortaya çıkarmaktır. Amerikan ve Asya kültürleri arasındaki ayrıntılı analiz, çalışmanın bulgularını desteklemek için sunulmuştur. Çalışmanın verileri için, YouTube'dan America's Next Top Model Session 21 Episode 5 ve Asia's Next Top Model Session 6 Episode 1'deki ifadeleri toplandı. Verileri analiz ederken tüm ifadeleri ortografik transkripsiyon yöntemi kullanarak yazıya döküldü. Veriler daha sonra analiz edildi ve nitel betimleme yöntemi kullanılarak Searle (1979) tarafından yazılan günlük konuşma eylemleri teorisi açısından sınıflandırıldı. Bundan sonra, toplanan verilere ve sonuçlara dayanarak bir yorum yapıldı ve daha fazla araştırma için öneriler getirildi. Analizden, toplam günlük konuşma dışı konuşma eylemlerinin 146 ifade olduğu sonucuna varılabilir (72 Amerika'dan ve 74 Asya'dan). America's Next Top Model'in ana türleri iddialı ve açılayıcıyken (\% 33,33), ifade işlevinin Asya'nın Sonraki Üst Modelinde en baskın olduğu ortaya çıktı. Kültürler arası pragmatik bakış açısına göre, bu çalışmanın sonuçları Asyalıların Amerikalılardan daha anlamlı olduğu sonucuna varıyor. Ek olarak, Amerika bağlamında bir özür beyanı varken, Asya bağlamında hiçbir özür ifadesi yoktu. Bu çalışmada, Amerikalıların Asyalılardan daha belirgin ya da aleni olduğu, Asyalıların da Amerikalılardan daha "dikkatli" olarak sınıflandırıldığı görülebilir.

Anahtar sözcükler: Konuşma eylemi; serbest konuşma eylemi; kültürler arası pragmatik; Amerika'nın Yeni En İyi Modeli; Asya'nın Yeni En İyi Modeli

\section{AUTHOR BIODATA}

Riza Alifianti Putri is currently a master's degree student in Linguistics at Universitas Airlangga Indonesia. She holds a bachelor's degree in English Language and Literature from Universitas Airlangga Indonesia. Her research interests include Pragmatics and Psycholinguistics.

Ni Wayan Sartini holds a PhD from Universitas Udayana, Indonesia. She is currently the Head of Master's Program in Linguistics at Universitas Airlangga, Indonesia. Her research interests include Cultural Studies, Pragmatics and Sociolinguistics.

Muchamad Sholakhuddin Al Fajri is a lecturer in English Language and Linguistics at Universitas Airlangga Indonesia. His research interests include Corpus Linguistics, (Critical) Discourse Analysis, and Pragmatics. 